\title{
9 Work-life balance and equality observed through advertising during the COVID-19 pandemic in Japan and Norway
}

\section{Chibiro Wada and Roger A. Søraa}

\section{Work and home under the COVID-19 pandemic}

The COVID-19 pandemic has altered the ways in which people live and work at home. New trajectories have emerged regarding the balance between work time and leisure. As pandemic lockdowns have confined people to their homes, the distinction between one's work life and home life has blurred. In turn, these changes have affected individuals' sense of their responsibility as workers and co-dwellers. How have people perceived this change? What new narratives have arisen to make sense of it? In this paper, we investigate how advertisements geared to national audiences represent Japanese and Norwegian households' ways of striking a balance between a new kind of work and home life. Specifically, we ask how advertisements envision balancing working at home during the pandemic while doing necessary housework and caregiving. We focus in particular on the perceptions of certain domestic tasks as gendered and narratives about the balance between work and home in everyday life.

Work is gendered and situated in material practices. Where we work, how we work, what we work with and whom we work with intimately shapes human beings as individuals and as members of different social groups, such as households. As the COVID-19 pandemic emerged during the early months of 2020, societies across the globe began to change drastically in multiple ways, particularly regarding how work is enacted as a material practice.

This global observation also holds true for Japan and Norway, the countries where we made our observations. Japan, with its customarily long workhours, strongly gendered barriers in the workplace and gendered division of domestic work may offer interesting ways in which a workforce faces the challenge of working from home. On the other side of the globe, the Norwegian workforce, with its short, efficient work hours, shows ways of working in the pandemic that are similar to but also quite different from those of the Japanese. The pandemic has changed societies in terms of where people work and how society envisions that workers will situate the socio-materiality of home and work. The challenges of this unexpected 
situation offer a ripe opportunity for advertisers to spin new narratives of work-home balance that integrates and sells their products. But how do advertisers handle this new situation, and what are their focus areas when it comes to remote work?

We compare these two work contexts through the conceptualisation of work from home through representations of work and family in advertisements. Social values are often reflected through commercials, which portray, satirise and otherwise comment on social structures and events (Cheng \& Schweitzer, 1996; Klassen et al., 1993; Kunkel \& Roberts, 1991), including the events of the COVID-19 pandemic. Ads also have the power to change social norms and impact how we relate to topics. We will argue that advertisements in both Japan and Norway have tended to focus on the newness of men's attention to housework and parenting amid the transition to remote work, while underscoring their essential role as the family's primary breadwinner. Similarly, women's roles as primary caregiver and homemaker remain unquestioned, while commercials express sympathy for their need to balance domestic duties with their paid employment. Family-centred commercials in both countries continue to identify the family as abled, cisgendered and heterosexual, although ads in Norway tend to allow for more diversity in this regard. In Japan, this idealised family belies the actual variety in household configurations.

We argue that advertisements geared to national audiences represent Japanese and Norwegian households' ways of dealing with the balance between a new kind of work and home life. Gendered narratives about the balance between work and home in everyday life can be seen through looking at how ads conceptualise the situation. These representations can thus provide valuable insight both on how 'work' and 'home' is gendered.

\section{Method and analytical approach}

We selected nationally broadcasted advertisements from Japan and Norway by searching for online advertisement videos released prior to December 2020. We ascertained their release dates based on those indicated on official webpages associated with the advertisements and the official YouTube channels of the companies that produced the videos. Videos were chosen as a media rich in content, narrative, and social commentary.

We performed content analysis on the framing of working from home in these video texts. A total of 54 advertisements from Japan were selected for analysis; these included ten advertisements that predated the pandemic period (released in the late 2010s), seven broadcast around the beginning of the pandemic period (January to March 2020) and 37 broadcast during the pandemic period (April to December 2020). Norway has a smaller commercial market than Japan, which implies fewer relevant commercials. Thus, for Norway, we selected a total of 49 advertisements: Ten that predated COVID-19, seven broadcast from around the onset of the pandemic 
outbreak and 32 broadcast during the pandemic period. A Google video search using the keyword 'COVID-19 commercial' conducted in June 2021 found over 101 million videos on the topic globally. By using the keyword 'Corona commercials' (Korona CM in Japanese), about 4.88 million videos were found in June 2021; the same search in Norwegian (korona reklame) yielded 119,000 results. These numbers show that this study cannot be considered a representative quantitative analysis over all possible commercials on the topic. However, this selection does shed light on the topic at hand in Japan and Norway, as they tell stories about how societies were adopting to new rules and norms during the pandemic. The text of the Japanese and Norwegian advertisements was translated into English by the authors.

In our analysis, we first explored gender and representations of home and work-life balance in advertisements in Japan and Norway that were broadcast before the pandemic, analysing their conceptions of workers. We then turned to pandemic-period advertisements with the same questions, which constitute the main part of our study. Investigating the topological connections between gender and work before and during the pandemic, we focused our analytical lens on the ways in which commercial depictions engrain and habituate roles, practices and symbolic meanings.

\section{Pre-pandemic: Work-related advertisements showing Japanese salarymen and Norwegian working mothers}

To understand the pandemic period, we first ground our analyses in advertisement depictions of work before the pandemic. Work and gender roles have long served as themes in advertisement and, at times, incited viewer outrage. The depiction of women in a 1975 advertisement for ramen by the Japanese corporation House Foods, for example, famously sparked controversy based on its celebration of a gendered division of labour in the home (The Asahi Shimbun Corporation, 1975, p. 23). A young woman and her small daughter are shown standing and singing that they are going to make ramen for the husband and father, who is sitting at the table. They are accompanied with the slogan, 'I'm the girl who makes it - I'm the guy who eats it,' (Watashi tsukuru bito, boku taberu hito).

Though Japanese advertisements often depict conventional gender norms, some changes in gender representation have been made. The representation of men cooking meals has increased since 1986 when the equal employment opportunity law was enforced (Yoshida, 1998, pp. 140-1). After 1991, when the bubble economy burst and employment amongst men fell, advertisements started to depict the emerging reality of men being at home with the children (Yoshida, 1998, p. 154). However, advertisements conventionally reflect gender norms and often describe women engaging in unpaid work at home while men work outside home (Nobeshima, 1998; Yoshida, 1998). The image of the suited salaryman, always busy at work, 


\section{2}

has been the conventional representation of the masculine ideal in postwar Japan (Abe et al., 2006; Connell, 2005, p. 200; Dasgupta, 2013). Contemporary advertisements continue to reflect these societal gender norms, even in the face of changing familial configurations, as seen in studies of Japanese television ads in the early 2000s (E, 2003; Pongsapitaksanti, 2008).

While political campaigns try to change the social situation, women still take the main responsibility of child-rearing in Japan. In 1999 the Japanese Ministry of Health, Labour and Welfare (MHLW) launched a campaign to ameliorate the declining birth rate. Further, in 2010, the MHLW launched its Ikumen Project, which called on men to participate in child-rearing. The neologism ikumen is composed of $i k u$, meaning 'to raise children' and the English word men - a wordplay on the slang expression ikemen (handsome men). However, despite this campaign, only $7.48 \%$ of eligible men took parental leave in 2019 (while $83.0 \%$ of eligible women took maternal leave) (Ministry of Health, Labour and Welfare 2020). While the number of men opting for parental leave is increasing especially after 2012, women still make up the overwhelming majority of those taking leave from work to raise children (see also Chapter 3 in this book).

Representation of male engagement in housework and childcare is often uncritically accepted by the viewers. In 2017, a diaper advertisement by Unicharm Corporation (Moony Promotion, 2017), which depicts a woman busy with housework and child-rearing while her husband does nothing, sparked controversy amongst the public. We see the reverse scenario in a 2014 advertisement for softener by Lion Corporation showing a busy house husband sawing or shopping all alone, which received no public backlash (Miyashita, 2020, p. 101). Miyashita (2020) argued that the commercial's intended viewership (probably women) likely regarded this scenario as unrealistic and the representation of a house husband purely fantasy (p. 101).

Advertisements broadcast before the coronavirus pandemic in Japan often depicted men in suits working long hours, but several also illustrated men working and raising children. ${ }^{1}$ While these attempts at disrupting hegemonic masculinity have sometimes led to mockery, ${ }^{2}$ such images endured in the pre-coronavirus Japan of the late 2010s. For instance, one advertisement for a drink that prevents hangovers in 2019 depicts suited men doing 'nomikai' - a Japanese custom to drink alcohol with their business associates after their work as a part of their business activity - with the product as they smile. ${ }^{3}$ However, nomikai is sometimes ridiculed as a bad example of a custom of long-working hours.

Going against the grain, some advertisements broadcast in Japan from the late 2010s show women at work and some even depict men raising children. A commercial for a toilet detergent, for example, depicts a woman wearing a suit at work and being tired of overwork. She suddenly cleans a toilet next to her desk and says 'It feels great!' (ST-Corporation, 2019). 
Although only one out of ten advertisements in our sample describes work from home, the protagonist of the advertisement was a man who was engaging in childcare. This coffee ad from Suntory Beverage \& Food Limited (2017) shows a young man raising children while working remotely, concluding with the motto, 'A new wind is blowing.' Reinforcing the 'newness' of this scene, the advertisement also shows people bringing their pet dogs to the office, suggesting the potential for new styles of work in Japan. Thus, advertising in the late 2010s, before the spread of the novel coronavirus, included depictions of conventionally suited salarymen and career women working busily away from home. Much less common were depictions of men taking part in housework and child-rearing.

Turning to Norway, we find an entirely different situation. Since the 1980s, Norway has required advertisement narratives to support gender equality politics (Berg et al., 1979):

1 In commercials with one person - flip the gender of the person shown to the opposite gender.

2 In commercials with both genders, let men and women change roles.

Berg et al. (1979) argued that as long as the resulting gender change did not require any alteration to the rest of the storyline of the advertisement, it would fairly represent and help normalise gender equity. Berg et al. also recommended that commercials use the same number of men and women. The strongest directive was that to flip gender roles, for example, to show compassionate men in caregiving roles and gregarious women meaningfully engaged in the public domain. A commercial for Telenor (1997) provides a good example of this. Seeking to discover what it calls 'solutions for the country' (loosely meaning, 'things that can be improved'), the commercial shows a working mother dealing with difficult male bosses. Clearly, they do not think that she can become an effective leader since she must care for her sick child. With the help of a female secretary, however, the woman manages to impress them while excelling at work and providing childcare. The message is thus that women can actually do it all just as well as men, but also that comradeship and sisterhood among working women should be applauded.

As we see, in both Norway and Japan, commercials have made groundbreaking representations of both domestic and working life and have also reinforced stereotypes. In both countries, the portrayal of the workingmother or career-woman balancing work and home life has surfaced as particularly important. Our study found, with few exceptions, the woman represented as a parent as well. Notably, Norwegian commercials depict women's careers as enhanced, not limited, by their having children, as we saw in the 'solutions for the country' video. They regularly portray childcare responsibilities in a way that shows women being able to handle multiple roles, issues and tasks. These positive maternal figures contrast 


\section{4}

with commercials featuring men, which often depict them as the implicitly single and childless career-man - or downplaying and not focusing on their role in the home life. Also, after the 2000s, particular scrutiny has been put on the retouching of commercial posters, and out of context body-focus, as Engesbakk (2007) discussed. Examples include companies selling contact lenses, but showing nude women sitting around (with little focus on their eyes), and the sexualisation of women drinking coffee and the general retouching of commercial posters, such as in H\&M underwear commercials.

The long-held social norm which positions the husband/father as the primary breadwinner and the wife/mother as primarily devoted to housework and child-rearing remains a powerful trope of middle-class life, especially in Japan. This conventional portrait often overshadows actual diversity in society, such as the increasing existence of single and LGBTQ+ households. In Japan, there has been little media representation of this variety, while in Norway, diversity of cast has been increasingly represented in recent years. In fact, in 2021, it is quite common to see portrayals of queer couples in commercials. This coincides with the Norwegian Labour and Welfare Administration's decision to move away from focusing policies primarily on housewife politics in the 1970s, to also including those regarding single parents and LGBTQ+ couples after the 2000s. This can be seen on their official site (Arbeids- og velferdsetaten [NAV], 2020), with thorough rules, for example, for gay and lesbian couples raising children together, with different rules for surrogacy and adoption cases. This trend has shaped commercials in Norway too, which increasingly spin scenarios involving various family compositions and close relations outside the traditional nuclear family model. In Norway, working from home was not often thematised in commercials before the pandemic. How did advertisers thematise working from home when this became a new norm during the COVID-19 pandemic?

\section{The pandemic era: Work-related advertisements in Japan and Norway}

Work-related advertisements that have appeared during the pandemic era in Japan and Norway show similar depictions of working from home and child-rearing as people adapt to the pandemic. However, these advertisements also reveal several differences between adaptations to this situation in the two countries.

Japanese advertisements have started depicting remote meetings as the representation of a new type of workstyle rather than a temporary workaround. These advertisements show working women and men mutually engaging in child-rearing and housework at home. But male participation in child-rearing tends to be the main theme, clearly marked as the 'newest' part of the new workstyle. In contrast, women's work receives less 
attention, signalling that women's productive labour in the workforce and reproductive labour in the home are hardly considered anything new.

On 7 April 2020, a state of emergency was declared in seven prefectures, including Tokyo, in response to the novel coronavirus pandemic. This period can thus be tentatively identified as the point when public concern was strongly drawn to the novel coronavirus in Japan, as foreshadowed by the Yokohama cruise-ship incident, an early instance of coronavirus in Japan in February 2020. Advertisers, too, responded to this concern, as around the time that people in Japan began to implement social distancing and take remote work seriously, many advertisements began to show multiple people communicating remotely via computers. Of the 16 ads which describe work from home in our sample from this period, 12 depict remote meetings using computers. An advertisement for a man's suit company, for example, depicts four men sharing work information on a computer screen (The Suit Company, 2020).

This increase of remote meetings portrayal reflects the new reality of remote working. The percentage of employees who experienced remote working has increased from 10.3\% (December 2019) to $27.7 \%$ (May 2020), which declined to $21.5 \%$ in December 2020 (Cabinet Office, 2021). Although there is a gap between different occupations, the overall number of people who experienced remote working increased, and commercials during this period reflected this situation.

Whereas commercials depict women 'balancing' paid work, childcare and housework, men are shown as adding childcare to their work from home. Interestingly, these ads are all produced by multinational companies, which may signal their adherence to representations of work acceptable in other developed countries. Moreover, while 10 out of the 16 pandemic-era advertisements in Japan in our sample present individuals working from home while engaged in housework or childcare, only one focuses solely on women. Many ads depict both men and women active together in their homes, but male engagement in child-rearing tends to be the main theme. It is the 'newness' that attracts viewer attention. For example, an advertising campaign on clothes appropriate for remote work launched by apparel manufacturer UNIQLO Co., Ltd., uses the catchphrase 'New normal. New workwear.' The version of the remote-wear product made for men features the slogan 'For work, for parenting,' while the slogan for the women's product states, 'Pants that make me feel positive.' The text on the website selling the same women's pants reads, 'Work, hobbies, parenting is never a zero-sum game. In this new lifestyle, they all matter.' The UNIQLO ads assume that today's women all continue to raise children as they work inside and outside the home, while men have added parenting as a new activity. ${ }^{4}$ An add from Kureha Corporation's advertisement for plastic food wrap also presents a working man engaging in housework and childrearing. The website for this campaign champions dual parent engagement housework and childcare as the trend, asserting, 'In more and more 
families, it is not a matter of who should do it, but of doing it together. ${ }^{5}$ These advertisements by UNIQLO and Kureha portray two-income families in which men participate in housework and child-rearing, although these were previously duties handled entirely by women.

The 'positive' representation of men engaging in childcare does not reflect a reality. Through experiencing remote working, women felt that their burden on housework and child-rearing increased while men enjoyed the decrease in commuting time and women were less satisfied than men with the sharing the burden of childcare and housework with their partners and $35.2 \%$ of them wanted their partners to do more housework (while only $18.5 \%$ of men wanted to) (Gender Equality Bureau Cabinet Office, 2020).

These observations will be re-examined comparatively after studying commercials designed and disseminated in Norway during the same period.

\section{Return of domestic work and noisy children in Norway}

Prior to the COVID-19 pandemic, it was found that in Norway $33 \%$ of employees reported being able to work from home from at least a half-day per month (Øksnes, 2018). However, working full-time in a permanent home office situation is quite different. After the first coronavirus infection was discovered in Norway, on 26 February 2020, the country took drastic measures and closed down on 12 March, with workers who were able to being asked to set up home offices, such that many people were working from home from March to December. As in Japan, this new normal, where individuals did not know how long their home office situation would last, led to many commercials and advertisements thematising and capitalising on the situation, both by portraying people working from home and by selling them equipment for their new work environment.

As a result, working from home themes became widespread in commercials during the pandemic. For example, the Norwegian commercial from mobile phone operator Telia released a commercial called 'The show must go online' (2020). Against the background music of the rock group Queen's well-known song, 'The show must go on,' the commercial features the tagline, 'Suddenly the internet became more important than pants.' The humorous commercial shows four people carrying on a job-meeting online from home (and without wearing trousers). A man in his 60s is comically shown wearing animal slippers and using a robot vacuum cleaner to dust his floor while he is in the meeting. A woman in her 40s, meanwhile, is shown using nail-polish on her toenails.

Gender roles also served as an important topic in relation to working from home. In a Norwegian commercial advertising the largest bank in the country, Den Norske Bank (2020), we are shown a multitude of people dealing with having to work from home. This commercial presents depictions of gender and work roles commonly found in other Norwegian commercials. Although both men and women are shown taking care of 
children through home schooling or other means in the commercials, quite different practices appear, too. For instance, women are often shown as engaged in self-care (cutting hair, polishing nails), but looking sad nonetheless about their confinement in the home. In contrast, men are shown enjoying their pandemic life by working out or having fun with pets; in one montage, we are even shown a man working out doing push-ups while a woman sits on his back. The product of the commercial is a telecommunication service of broadband being sold, so what the people do with the increased internet speed as portrayed in the commercial can be quite broad.

The COVID-19 crisis has had gendered consequences, especially in regard to work. Globally, women constitute $70 \%$ of the healthcare workforce on the frontline of the pandemic (Pozzan \& Cattaneo, 2020). Evidence shows that during the pandemic, Norwegian women have devoted more time to their domestic work and care work due to working from home, including increased care tasks for both older and younger generations (Nergaard, 2020). One rector at a Norwegian university, for example, suggested that female workers should be given priority when returning to university work to compensate for their pandemic caregiving burdens (Strand \& Schei, 2020). These issues about women's labour at home and in healthcare have not seemed to translate into the world of advertisement, which often focuses women's engagement in self-care.

Children, interestingly, often play the role of 'noisy villains' in commercials. For example, a commercial by one of the largest building-stores, Byggmax (2020), depicts a man intentionally locking himself out of his home in order to escape his noisy children. In most commercials featuring children, focus is put on how noise adds a negative layer to the home, enhancing the sense that things are out of place. Although one could argue that children, not work, are the natural habitants of the modern home, commercials imply that the pandemic has upset the norm. Norwegian childcare policies have focused on enabling women to work through improved state-supported public kindergarten services.

A Norwegian labour force survey of the population aged 15-74 showed $73.8 \%$ male work employment and $67.9 \%$ female work employment, with $36.8 \%$ of women working part-time, compared to $12.5 \%$ of males (Statistisk Sentralbyrå [SSB], 2019). This part-time model is often coupled with unpaid informal care-work responsibilities.

The 'noisy children' trope in commercials reflects the disruption caused by a lack of the normal access to childcare in Norway during the pandemic. The Norwegian societal model of the welfare state, which enables a high participation of women in employment, is thus now under stress. Institutions have closed down or are quarantining, thereby increasing domestic and care responsibilities within households. Although the 'working mom' trope as a model of women working after having children faces new challenges due to the pandemic with digital home-schools, the measures that have been taken hastily in the pandemic do not necessarily aim to 
prevent or mitigate this threat, but rather is a measure to get by for now. The advertisements analysed did not problematise to any significant degree the increased burden of care on women, but they did show many fathers taking on care responsibilities.

\section{Comparing Japan and Norway: Emerging paradoxes}

The pandemic has made working from home necessary for a wide variety of workers. Our examination of Norwegian and Japanese advertisements previous to and during the pandemic has uncovered common themes. Most pertinent to our study were narratives about the balance between domestic work and paid work, both of which took place in the home to a greater degree during the pandemic. Prior to the pandemic, Japanese women spent 208 minutes per day on housework, compared to 44 minutes for men in 2016 (Statistics Bureau Japan, 2017). Even though Japanese women now need less time for housework than they did 20 years ago, they still hold more responsibility for it than men, which can be linked to sociocultural factors.

Women in Norway also still do more housework than men, spending 110 minutes a day on average, compared to 60 minutes for men. Yet, there has been movement toward gender equity in Norway: Women have more than halved the time they spend on housework over the last 50 years, partly due to technology and more efficient ways of doing housework, while men have increased their time by $55 \%$ (Bufdir, 2016). It is interesting to note that $52 \%$ of Norwegian men but only $36 \%$ of Norwegian women feel that the responsibility for housework is shared equally. Although Norwegian women do less domestic housework than they did in the 1970s, and men do more, the balance is still unfavourable to women (Vaage, 2012). Ellingsæter \& Kitterød (2021) found that Norwegian fathers do both more housework and care work, which they thematise as 'family work,' but that women still do much more of all categories. Also worth noting is the socio-economic aspect, as men with higher education do more than those with lower education, according to Ellingsæter \& Kitterød (2021).

Gender inequality in housework responsibilities is closely related to the cultural definition of expectations for both domestic life and what constitutes normal. As depictions of remote work increase, advertising has come to show more scenes depicting work-life balance, which in Japan generally relates to the 'new' trend of men's involvement in raising children. As noted above, in our sample, advertising in Japan has featured depictions of working women and men raising children and doing housework since the late 2010s. However, at the same time as those developments, the image of the busy salaryman has also remained common in Japan. Beginning with the spread of the novel coronavirus, depictions of remote work in Japan in ads have increased, and men's participation in child-rearing has come to be portrayed in a positive light. However, conventional family norms are still 
being represented and recapitulated and women are being pushed to the margins by men's representation. In the advertisements in Norway, we noted in particular that although fathers were positively represented when shown taking care of their families, the families themselves were not always portrayed positively. Children were often portrayed as noisy disturbances for the man working from home. Women portrayed working from home were often shown as angry or depressed, as well as overly interested in selfcare through their use of beauty products. Our analysis has led us to three gender work paradoxes for further enquiry, as described in the following subsections.

\section{Reworking the happy family myth}

Many advertisements appear to challenge conventional gender norms but traditional family roles are quietly reworked into the context of the novelty of remote work. As the above analysis indicates, the advertisements collected here tend to depict heterosexual couples raising abled children, with both parents working and sharing housework and parenting responsibilities. While this was true in both contexts, it was particularly evident in the Japanese selection. Diverse families such as those of single people, single-parent households, same-sex couples, or families without children appear very seldom in Japanese commercials compared to the Norwegian ones. Remote work serves as a prompt to integrate women's work inside and outside the home and adds men's housework and child-rearing to existing family norms, amid the continuing depiction of the conventional happy, abled and heterosexual family.

\section{The marginalisation of women}

Our analysis of advertisements in Japan and Norway highlights the depiction of remote work and men's participation in child-rearing, as well as how this depiction reflects women's double burden. The novelty of remote work reflected in the Japanese advertisements analysed is mainly attributed to men's home life and not to women's work life. Styles of work in twoincome households have undoubtedly changed for both men and women, and the focus in advertisements is on the men who are participating in housework and child-rearing - or as we saw in Norway, their use of robot vacuum cleaners to avoid housework. The advertisements discussed do not focus much on how housework and child-rearing has actually changed for women in the pandemic, and often risk reproducing gender stereotypes.

\section{Technologies alone do not bring equality}

We might expect that advancing technologies could diminish housework, thereby reducing concerns about who has responsibility. Novel technologies, 
however, do not by themselves rewrite conventional gender roles (see Wajcman, 1991); rather, we must continue to discuss the meanings attached to women's labour in society. We do not see any attempt, however, to draw attention to this issue in contemporary advertisements. The move of leaping directly to depictions of men's novel participation in housework and child-rearing, while bypassing the women who are the ones actually taking parental leave or shouldering both work and household duties, has an insidious effect, although we do see in the examples of the noisy children in commercials that parenting is not presented as being without friction.

\section{Conclusion}

This chapter has investigated how advertisements in Japan and Norway have portrayed the novel COVID-19 pandemic's effect on work. This has been done by selecting and analysing advertisements in Japan and Norway for their portraits of new configurations of remote work and their effect on gender roles within the family. The primary advertisements chosen were first published during the COVID-19 pandemic, with some earlier ones analysed as well to contextualise the two countries. In Japan, the image of the busy, suited male salaryman of the late 2010s is retained, but the newer advertisements also use images of remote meetings on computer screens to symbolise remote work, concurrently evoking the participation of men in housework and child-rearing as desirable. More often, the changes in men's tasks is the focus, while women do not feature much in the changed portrayals of home-work balance. In Norway, the reworking of the workingmom trope continues to be portrayed in the pandemic-themed advertisements, but here as well, fathers are also featured. Children were not portrayed in a favourable manner in many instances, but a tension was shown between quiet workplaces and noisy homes in multiple commercials. Our analysis of the commercials focused on lifestyles, styles of work and ideas of gender depicted therein. In comparison, while these advertising trends depicted the novel topics of remote work and men's participation in housework and parenting, under the surface they continued to perpetuate conventional family norms as well as the marginalisation of women. This was the case for both Japan and Norway, but with less diversity of gender roles in Japan, apart from a remarkable focus on men's involvement in child-rearing roles. The question of whether the society-transforming event of remote work during the COVID-19 pandemic has changed gender roles in the home should wait for a post-pandemic study, but our enquiry into the world of advertisements suggests that work-life balance and equality are undergoing novel gendered tensions through this sudden rebalancing between work and home. 


\section{Notes}

1 The products promoted here include coffee and a web magazine.

2 One advertisement for an air freshener depicts a busy salaryman who sings to enjoy his work. Viewers are expected to be sympathetic to him and at the same time, laugh at the situation.

3 The original video by Kowa Company Ltd. has been removed.

4 These differences were seen in September 2020. The website has been changed and the same text was seen to be used for both women and men in March 2021. https://www.uniqlo.com/jp/ja/contents/feature/smart-pants/women/

5 The original video has been removed.

\section{References}

Abe, T., Obinata, S., \& Amano, M. (Eds.). (2006). Danseishi3: Otoko rashisa no gendaishi. [Contemporary history of 'manliness']. Nihonkeizaihyouron Sha.

Arbeids- og velferdsetaten. (2020). Foreldrepenger. [Parental benefits]. [Website]. https://familie.nav.no/om-foreldrepenger

Berg, A.M., Kallerud, B., \& Melby, K. (1979). Reklame og kjønn: en utredning om kjønnsundertrykkende reklame. [Advertising and gender: A study of gendersuppressing advertising]. [Report]. https://www.nb.no/nbsok/nb/4878fa7c57b612 8af532544b0f0f965f?index=1

Bufdir. (2016). Tidsbruk og kjønnsforskjeller [Time use and gender differences]. [Report]. https://bufdir.no/Statistikk_og_analyse/kjonnslikestilling/Familie_og_kjonn/Tidsbruk/\# : :text=Av\%20alt \%20husholdsarbeid \%20er\%20det,sin \%20tid\%20brukt $\% 20 \mathrm{p} \% \mathrm{C} 3$ $\%$ A5\%20husarbeid

Byggmax. (2020). John blir handy - Hjemmekontor [John becomes handy - Home office]. [Video]. YouTube. https://www.youtube.com/watch?v=52JGV6TRX-I\& ab_channel=ByggmaxNorge

Cabinet Office. (2021, 4 June). Dai sankai shingata koronauirusu kansenshou no eikyouka niokeru seikatsuishiki - koudou no benka ni kansuru chousa [The 3rd survey on transition of the general public's views and behaviour under the novel coronavirus pandemic]. [Report]. https://www5.cao.go.jp/keizai2/wellbeing/ covid/pdf/result3_covid.pdf

Cheng, H., \& Schweitzer, J.C. (1996). Cultural values reflected in Chinese and US television commercials. Journal of Advertising Research, 36(3), 27-46.

Connell, R.W. (2005). Masculinities (2nd ed.). University of California Press.

Dasgupta, R. (2013). Re-reading the salaryman in Japan crafting masculinities. Routledge.

Den Norske Bank. (2020, 20 March). Hjemme fra A til $\AA$ [Home from A to $\AA$ ] [Video]. YouTube. https://www.youtube.com/watch?v=eQXZmByYdnk\&ab_ channel=DNB

E, J. (2003). Terebi koukoku ni okeru jenda byousha no nikkan hikaku kenkyu [A comparative content analysis on the gender portrayals in Japanese and Korean TV commercials]. Tetsugaku, 110, 37-57.

Ellingsæter, A.L., \& Kitterød, R.H. (2021). Den 'uferdige' revolusjonen: Hva betyr utdanning for fedres familiearbeid? [The 'incomplete' revolution: What does education mean for fathers' domestic work?]. Tidsskrift for samfunnsforskning, 62(1), 27-50. 
Engesbakk, S. (2007). Reklame, kvinne og reklamekvinnen: En undersøkelse av markedsføringen mot kvinnen og de etiske konsekvenser dette får. (Advertising, women and the advertising woman: A study of marketing towards women and the ethical consequences this has). [Bachelor's thesis]. Umeå University. http:// www.diva-portal.org/smash/record.jsf?pid=diva2\%3A140434\&dswid=4501

Gender Equality Bureau Cabinet Office. (2020). Reiwa ni nendo 'Danjyo kyoudou sankaku no shiten karano shingata koronauirusu kansenshou taisaku ni kansuru chousa' chuukan houkoku sho [Year 2020 'Survey on novel coronavirus control from the viewpoint of gender equality an interim report]. [Report]. https:// www.gender.go.jp/kaigi/kento/covid-19/siryo/pdf/5-5.pdf

Klassen, M.L., Jasper, C.R., \& Schwartz, A.M. (1993). Men and women: Images of their relationships in magazine advertisements. Journal of Advertising Research, 33(2), 30-40.

Kunkel, D., \& Roberts, D. (1991). Young minds and marketplace values: Issues in children's television advertising. Journal of Social Issues, 47(1), 57-72.

Ministry of Health, Labour and Welfare. (2020, July). Reiwa gannendo koyou kintou kihon chousa [Basic survey of gender equality in employment management in 2019]. [Report]. https://www.mhlw.go.jp/toukei/list/dl/71-r01/03.pdf

Miyashita, M. (2020). Gendai nihon no raifusutairu to jenda: enjyou jidai kara kangaeru [Modern Japanese lifestyle and gender: Consideration of advertising in an age of 'flaming']. Journal of Studies on Humanities and Public Affairs of Chiba University, 40, 93-111.

Moony Promotion. [@moonypromotion]. (2017, 19 April). Muni ga okuru hajimeteno ikuji ni funtousuru mama ni okuru ouenka 'moms don't cry' Uemura Kana san no utagoe nimo chuumoku [A cheering song 'moms don't cry' by moony for a new mother who experienced for the first time taking care of children, the singing voice by Kana Uemura to watch] [Video attached] [Tweet]. Twitter. https://twitter.com/moonypromotion/status/854611454875508736

Nobeshima, A. (1998). Nihon no terebi koukoku ni okeru jenda byousha [Gender representation in Japanese television commercials]. Koukokukagaku, 36, 1-14.

Nergaard, K. (2020). Hjemmekontor og digitale løsninger. [Home office and digital solutions]. [Report]. https://fafo.no/images/pub/2020/300420-hjemmekontorfaktaflak.pdf

Pongsapitaksanti, P. (2008). Terebi koukoku ni okeru jenda to roudou yakuwari: nihon to tai no hikaku kara [Gender and working roles in television commercials: A comparison between Japanese and Thai television commercials]. Soshioroji, 52(3), 71-86.

Pozzan, E., \& Cattaneo, U. (2020). Women health workers: Working relentlessly in hospitals and at home. International Labour Organisation. [Report]. https:// www.ilo.org/global/about-the-ilo/newsroom/news/WCMS741060/lang--en/index.html

Statistisk Sentralbyrå. (2019). Fakta om likestilling [Facts about equality]. [Report]. https://www.ssb.no/befolkning/faktaside/likestilling

Statistics Bureau Japan. (2017). 2016 Survey on time use and leisure activities: Summary of results (QuestionnaireA). [Report] http://www.stat.go.jp/english/ data/shakai/2016/pdf/timeuse-a2016.pdf

ST-Corporation. (2019, 2 December). Senjyouriki ofisu hen 15 byou [Senjyouriki office version 15 minutes] [Video]. YouTube. https://youtu.be/BfSEsdQFxt8 
Strand, H.K. \& Schei, A. (2020). OsloMet-rektor Rice vil la kvinner komme tilbake på jobb før menn [OsloMet Rector Rice will let women return to work before men]. Khrono. https://khrono.no/oslomet-rektor-rice-vil-la-kvinner-komme-tilbake-pa-jobbfor-menn/485546

Suntory Beverage \& Food Limited. (2017, 19 March). Kurafuto bosu shin TV-CM 'Atarashii kaze' hen [Craft Boss new TV-CM 'a new wind' version]. https:// www.suntory.co.jp/softdrink/news/pr/article/SBF0518.html

Telenor. (1997). Løsninger for landet. [Solutions for the country] [Video]. YouTube. https://www.youtube.com/watch?v=sQP6Puh5VK4\&ab_channel=Teiprester

Telia. (2020, 9 April). The show must go online [Video]. YouTube. https:// www.youtube.com/watch? v=LiqyH9nPhCA

The Asahi Shimbun Corporation. (1975, 28 October). Tsukuru hito taberu hito 'sabetsu CM' yamemasu jyoseino kougi ni 'kousan' housou ha kongetsu kagiri'Danjyosabetsu' CM [Removing the 'descrimitation CM' - I'm the girl who makes it - I'm the guy who eats it. 'Surrender' to women's objection. It will be deleted by the end of this month - 'gender discrimination' CM]. Asabi Shimbun, 23.

The Suit Company. (2020, 18 May). Okcal SHIRT rimoto kaigi hen 15 byou [Okcal SHIRT remote meeting version 15 minutes] [Video]. YouTube. https:// youtu.be/125v6qo73Bg

Vaage, O.F. (2012). Tidene skifter: Tidsbruk 1971-2010 [The changing times: Time use 1971-2010]. Statistisk sentralbyrå. [Report]. https:/www.ssb.no/a/publikasjoner/pdf/ sa125/sa125.pdf

Wajcman, J. (1991). Feminism confronts technology. Polity Press.

Yoshida, K. (1998). Terebi komasharu no naka no kazokuzou no hensen [The transition of family images in television commercials]. In Y. Matsumura \& $\mathrm{H}$. Gössmann (Eds.), Media ga tsukuru jenda: Nichidoku no danjyo, kazokuzou wo yomitoku [Gender in making by media: Analysing gender, family images in Japan and Germany] (pp. 136-160). Shinyo Sha.

Øksnes, K. (2018, 9 July). I disse yrkene er fleksibel arbeidstid mest utbredt [In these occupations, flexible working hours are most common]. Pengenytt. https:// www.pengenytt.no/i-disse-yrkene-er-fleksibel-arbeidstid-mest-utbredt/ 